\title{
PEMBINAAN KEPARIWISATAAN MELALUI PELATIHAN TEKNIK PRESENTASI KULINER LOKAL DI DESA WISATA MENGWI KECAMATAN MENGWI KABUPATEN BADUNG
}

\author{
I Nyoman Tri Sutaguna ${ }^{1}$, Ni Made Ariani ${ }^{2}$, Ni Nyoman Sri Aryanti ${ }^{3}$, dan Ida Ayu Eka \\ Trisna Putri ${ }^{4}$
}

\begin{abstract}
ABSTRAK
Desa Wisata Mengwi mempunyai Makanan dan Minuman Tradisional yang khas, yang dapat dikembangkan sebagai wisata kuliner (culinary tourism). Selain bentuk dan rasa, cara pengolahan dari bahan mentah sampai menjadi makanan dan juga dalam proses penyajiannya merupakan atraksi yang sangat menarik. Penyelenggaraan usaha makan dan minum tersebut merupakan salah satu bagian dari kehidupan pedesaan yang perlu dijajagi kemungkinannya untuk bisa dikembangkan sebagai media interaksi antara masyarakat dan wisatawan. Bentuk dari usaha ini dapat berupa kegiatan : makan bersama (dinner, lunch dan sebagainya) di lokasi desa, usaha pembukaan restoran, coffe shop di tempat-tempat strategis desa, serta kegiatan kursus masak-memasak Makanan Khas Daerah Bali seperti megibung dan sebagainya. Programprogram seperti ini memerlukan penyuluhan dan pelatihan baik terhadap penyajian (presenting) maupun kualitas makanan dan kesehatannya. Sehubungan dengan hal tersebut di atas, dalam rangka pengembangan Desa Wisata Mengwi sebagai desa wisata, maka perlu juga dikembangkan usaha Makanan Khas Daerah Bali sebagai media interaksi antara masyarakat dan wisatawan dan juga sebagai wisata kuliner (culinary tourism) di Desa Wisata Mengwi, Kecamatan Mengwi, Kabupaten Badung. Model kuliner yang dapat dikembangkan di Desa Wisata Mengwi seperti : Jukut Ares (appetizer/makanan pembuka). Nasi Sela, Tipat Cantok, Ayam/Bebek Betutu, Be Guling, Lawar Gedang, Jukut Urab (main course/makanan utama). Tape Ketan, Jaje Uli,Jjaja Dadar, JajaTtimus, Kolak Biu /sela (dessert/ makanan penutup). Semua kuliner tersebut dapat diadaptasi ke gastronomi internasional baik dari segi bentuk, tujuan, dan makna yang meliputi adaptasi bahan makanan, rasa, pengolahan, penataan/penyajian dan cara makan, sehingga dapat disajikan untuk wisatawan.
\end{abstract}

Kata kunci : pengembangan, makanan khas daerah Bali, wisata kuliner

\begin{abstract}
Mengwi village has its special characteristic traditional foods ad beverages which can be developed as culinary tourism. Beside taste and the form of the foods, the cooking process from the ingredients until become the ready foods, and the presentation of the foods can be the interesting attraction to offer. Organizing the traditional food and beverages of Mengwi Village which is the part of the daily life in this

\footnotetext{
${ }^{1}$ Jurusan Diploma IV Pariwisata, Fakultas Pariwisata, Universitas Udayana, Bukit Jimbaran, Badung Telp/Fax: 0361 224133,trisutaguna@unud.ac.id

2 Jurusan Diploma IV Pariwisata, Fakultas Pariwisata, Universitas Udayana, Bukit Jimbaran, Badung Telp/Fax: 0361 224133, ayukariani97@yahoo.com

${ }^{3}$ Jurusan Diploma IV Pariwisata, Fakultas Pariwisata, Universitas Udayana, Bukit Jimbaran, Badung Telp/Fax: 0361 224133,sriaryanti@yahoo.com

${ }^{4}$ Jurusan Diploma IV Pariwisata, Fakultas Pariwisata, Universitas Udayana, Bukit Jimbaran, Badung Telp/Fax: 0361 224133,dayutrisna_satria@yahoo.co.id
} 
village need to be measuring to be developed as the interaction tools and media among the local community and the tourist. The activities form such as; eating and enjoy the food together ( for lunch or dinner, etc ), organizing the restaurant, coffe shop, or cafe in the strategic location surround the village, cooking course for the women organization and the other programs. These programs of course need the education, training axercise and also the workshop how to make good presentation, improve the quality according to international standard, and also the sanitation and hygine. According to develop Mengwi Village become a Tourism Village as one of tourist object, the organizing traditional food and beverages business can be develop as the culinary tourism so that the local community can interacting directly with the tourist in Badung. The type of culinary which can be develop in Mengwi such as : Jukut Ares as a appetizer. Nasi Sela, Tipat Cantok, Betutu, Be Guling, Lawar Gedang, Jukut Urab as the main course. Tape Ketan and Jaje Uli,, Jaje Dadar, Jaje Timus, Kolak Biu/Sela as the dessert. All of these culinary can be adapted to the international gastronomy from the form, purpose and essential so that can be presenting and offered to the tourist.

Keywords; developing, traditional Balinese foods, culinary tourism

\section{PENDAHULUAN}

Konsep penggalian komponen produk (atraksi, amenities dan aksesibilitas) Desa Wisata Mengwi didasarkan pada pengembangan interaksi sosial budaya dari manusia ke manusia (masyarakat desa dengan wisatawan) dan dari manusia ke lingkungan). Bentuk interaksi tersebut bertujuan untuk mencapai keutuhan pengalaman tidak hanya bagi wisatawan, melainkan juga masyarakat desa, dalam rangka meningkatkan kualitas hidupnya. Berbagai macam atraksi yang mungkin dikembangkan meliputi kegiatan : persawahan, kesenian desa, upacara keagamaan termasuk juga Makanan dan Minuman Tradisional.

Desa Wisata Mengwi juga mempunyai Makanan dan Minuman Tradisional yang khas, yang dapat dikembangkan sebagai wisata kuliner (culinary tourism). Selain bentuk dan rasa, cara pengolahan dari bahan mentah sampai menjadi makanan dan juga dalam proses penyajiannya merupakan atraksi yang sangat menarik. Penyelenggaraan usaha makan dan minum tersebut merupakan salah satu bagian dari kehidupan pedesaan yang perlu dijajagi kemungkinannya untuk bisa dikembangkan sebagai media interaksi antara masyarakat dan wisatawan. Bentuk dari usaha ini dapat berupa kegiatan : makan bersama (dinner, lunch dan sebagainya) di lokasi desa, usaha pembukaan restoran, coffe shop di tempat-tempat strategis desa, serta kegiatan kursus masakmemasak Makanan Khas Daerah Bali seperti megibung dan sebagainya. Program-program seperti ini memerlukan penyuluhan dan pelatihan baik terhadap penyajian (presenting) maupun kualitas makanan dan kesehatannya.

Sehubungan dengan hal tersebut di atas, dalam rangka pengembangan Desa Wisata Mengwi sebagai desa wisata, maka perlu juga dikembangkan usaha Makanan Khas Daerah Bali sebagai media interaksi antara masyarakat dan wisatawan dan juga sebagai wisata kuliner (culinary tourism) di Desa Wisata Mengwi, Kecamatan Mengwi, Kabupaten Badung.

Tujuan kegiatan ini adalah untuk memberikan tambahan pengetahuan serta keterampilan kepada masyarakat di Desa Wisata Mengwi mengenai Makanan Khas Daerah Bali yang baik yang dapat memenuhi kebutuhan wisatawan sehingga dapat sebagai penunjang wisata kuliner (culinary tourism) dalam pengembangan Desa Wisata Mengwi sebagai desa wisata.

\section{METODE PELAKSANAAN}

Kegiatan ini dilaksanakan dengan cara memberikan pengetahuan dan keterampilan dengan ceramah/penyuluhan dan diskusi mengenai wisata kuliner termasuk didalamnya bagaimana 
cara/latihan/praktek mengolah makanan khususnya Makanan Tradisional Bali yang baik untuk dikonsumsi kepada wisatawan.

\section{HASIL DAN PEMBAHASAN}

Pelaksanaan kegiatan pengabdian kepada masyarakat di Desa Wisata Mengwi dihadiri oleh Kepala Desa/Lurah Mengwi beserta staff, serta ibu-ibu PKK, dan sangat antusias dan semangat untuk menghadiri dan mengikuti kegiatan pengabdian dari awal sampai akhir, dan juga sangat semangat untuk ikut terlibat dalam pelatihan /praktek pembuatan Makanan Tradisional Bali yang dimodifikasi ke modern sehingga dapat disajikan bagi wisatawan. Kegiatan pengabdian kepada masyarakat ini diawali dengan melaksanakan penyuluhan pengembangan wisata kuliner di Desa Wisata Mengwi, Kecamatan Mengwi, Kabupaten Badung, yang berhasil menyampaikan pengetahuan tentang pengembangan wisata kuliner kepada tokoh masyarakat yaitu kepala desa/Lurah beserta staff serta ibu-ibu PKK Desa Wisata Mengwi. Adapun materi penyuluhan yang disampaikan yaitu tentang "Pengembangan Makanan Khas Daerah Bali Sebagai Wisata Kuliner (Culinary Tourism) di Desa Wisata Mengwi, Kecamatan Mengwi, Kabupaten Badung”. Materi lebih ditekankan pada potensi yang dimiliki oleh Desa Wisata Mengwi yaitu hasil pertanian dan perkebunan dan pengembangannya dapat dilakukan dengan cara mencari penunjang dari hasil pertanian/perkebunan tersebut serta untuk menunjang industri kerajinan kayu dengan wisata kuliner.

Pengertian mengenai wisata kuliner dipaparkan terlebih dahulu dalam penyuluhan tersebut agar masyarakat terutama yang menghadiri yaitu ibu-ibu PKK lebih mengenal, mengerti dan paham mengenai wisata kuliner itu sendiri. Menurut Echols dan Shadily dalam Sudina 2007) menyatakan bahwa, istilah wisata kuliner secara leksikal berasal dari kata wisata dan kuliner. Wisata (pariwisata) berarti perjalanan orang-orang dari suatu Negara atau daerah menuju ke suatu negara atau daerah lainnya dengan tujuan bersenang-senang. Sedangkan kuliner berasal dari Bahasa Inggris yaitu culinary yang berarti berhubungan dengan dapur atau masakan. Wisata kuliner berarti perjalanan wisata yang dilakukan oleh seseorang atau melompok orang pada suatu negara atau daerah, dimana mereka (wisatawan) menikmati masakan khas negara atau daerah yang dikunjungi. Wisata kuliner bukanlah sesuatu yang mewah dan eksklusif. Wisata kuliner menyangkut semua pengalaman gastronomi yang unik dan mengesankan, bukan hanya restoran yang mewah tetapi juga termasuk makanan dan segala jenis minuman. Wisata kuliner bukanlah hal yang baru, berhubungan dengan agrowisata (hasil pertanian dan perkebunan), namun lebih terfokus pada bagaimana suatu makanan maupun minuman dapat menarik kedatangan wisatawan untuk menikmati. Wisata kuliner dapat ditemui di daerah perkotaan maupun pedesaan dan selalu tersedia sepanjang tahun.

Wisata kuliner mempunyai peranan yang penting, beberapa alasan diantaranya yaitu : (1) hamper semua wisatawan makan di luar selama melakukan kegiatan wisata; (2) aktivitas makan merupakan aktivitas yang digemari wisatawan; (3) tagihan yang lebih tinggi dari total tagihan wisatawan kemungkinan besar dihabiskan untuk kebutuhan makan dan minum; (4) wisatawan sangat senang berpartisipasi dalam kegiatan rekreasi di luar ruangan; (5) perhatian atau minat pada wisata kuliner menjangkau pada semua kelompok umur; (6) masakan lokal merupakan salah satu pendorong dalam memilih suatu destinasi wisata. Salah satu contoh aktivitas yang memenuhi persyaratan sebagai objek dan daya tarik wisata kuliner yaitu sebuah produk makanan maupun minuman yang unik dan mengesankan dari perkebunan, pertanian maupun peternakan seperti resep rahasia turun-temurun yang memiliki kekhasan dan rasa terbaik.

Pada penyuluhan tersebut juga diuraikan mengenai pengembangan Makanan Khas Daerah Bali sebagai wisata kuliner (culinary tourism) di Desa Wisata Mengwi. Berkaitan dengan Makanan Khas Daerah Bali, pengertian makanan dalam kognitif orang Bali meliputi konsep halal dan enak. 
Makanan Khas Daerah Bali dapat diartikan sebagai makanan yang diolah dan dibuat oleh masyarakat lokal Bali secara turun temurun dan menggunakan perpaduan bumbu lokal (basa) yang memiliki rasa dan aroma spesifik yang tidak dimiliki oleh daerah lainnya. Dengan semakin berkembangnya makanan khas daerah tersebut, akan memberikan kesempatan bagi masyarakat lokal untuk bersaing di era pasar bebas, termasuk Bali yang menjadi daerah tujuan wisata dunia. Berbagai wisatawan dari berbagai negara berbaur di Bali sebagai daerah tujuan wisata yang sebenarnya memiliki berbagai ragam makanan khas daerah. Keragaman Makanan Khas Daerah Bali teramat sangat mendukung untuk mewujudkan Makanan Khas Daerah Bali sebagai tuan rumah pada daerah tujuan wisata internasional baik dilihat dari gastronominya maupun komposisi menu.

Berdasarkan uraian di atas dan pengamatan di lapangan, menunjukkan potensi yang layak dijual kepada wisatawan di Desa Wisata Mengwi telah dicoba untuk dikemas menjadi suatu produk unggulan dan produk alternatif, salah satunya wisata kuliner. Meskipun keunggulannya adalah kerajinan kayu, namun potensi budaya yang unik terutama yang terkait dengan pertanian dan budaya lainnya yang unik perlu mendapat perhatian di dalam pengembangan Desa Wisata Mengwi sebagai objek wisata/daerah pariwisata. Seni kuliner Bali sebagai salah satu aspek kebudayaan Bali diadaptasi sehingga dapat menjadi wisata boga (wisata kuliner). Adaptasi tersebut dari segi bentuk, tujuan dan makna yang meliputi adaptasi bahan makanan, rasa, pengolahan, penataan/penyajian dan cara makan. Seni kuliner Bali sebagai penunjang pariwisata berdampak budaya, sosial, rasa bangga serta pemenuhan kebutuhan harga diri. Adapun contoh model wisata kuliner yaitu : bisnis perorangan, bisnis organisasi/hotel, bisnis desa adat. Model kuliner yang dapat dikembangkan di Desa Wisata Mengwi seperti :

1) Appettizer (makanan pembuka)/soup :

a. Jukut ares yang terbuat dari batang (gedebong) pisang

b. Acar/ rujak cuka

2) Main course (makanan utama)
a. Nasi sela
b. Tipat cantok
c. Ayam/bebek betutu
d. Babi guling
e. Jukut urab
f. Lawar gedang

3) Minuman
a. Es daluman
b. Jus ubi/sela
c. Jus durian

3) Dessert (makanan penutup)
a. Tape ketan
b. Jaja uli
c. Jaja dadar
d. Jaja timus
e. Kolak pisang/sela

4) Camilan

a. Sela rebus

b. Keripik singkong/pisang

Semua makanan tersebut memakai bahan alami, tanpa bahan pengawet dan pewarna buatan dikurangi dan yang paling penting yang perlu diperhatikan adalah sanitasi dan hygienenya.

Pada kegiatan pengabdian masyarakat di Desa Wisata Mengwi juga diberikan pelatihan/praktek mengenai pembuatan/pengolahan Makanan Khas Daerah Bali dengan bahan yang terdapat di perkebunan masyarakat. Pada pelatihan tersebut ibu-ibu PKK diberikan pelatihan pembuatan salah satu dessert (makanan penutup) yaitu jaja dadar /jajan (kue) dadar yang dibuat secara 
modern/internasional, dimana istilah asingnya adalah pancake sehingga jajan tersebut dapat disajikan secara internasional kepada wisatawan. Adapun bahan yang dipergunakan adalah tepung terigu dengan durian, sehingga jajannya bercita rasa durian. Sedangkan untuk topping (di atasnya) dipakai buah-buahan yang ada di perkebunan masyarakat pula seperti jeruk. Setelah mengolah makanan, Ibu-ibu juga diberi pelatihan utnuk menyajikan makanan yang diolah secara internasional dengan pembuatan garnish (hiasan) dari makanan yang dibuat sehingga menjadi menarik.

Kegiatan pengabdian kepada masyarakat di Desa Wisata Mengwi cukup berhasil dimana masyarakat terutama ibu-ibu PKK sangat antusias mengikuti kegiatan tersebut dari awal sampai akhir, sehingga mereka mempunyai pengetahuan mengenai pembuatan Makanan Khas Daerah Bali yang dapat disajikan kepada wisatawan.

\section{SIMPULAN DAN SARAN}

\subsection{Simpulan}

Dari kegiatan pengabdian kepada masyarakat mengenai "Pengembangan Makanan Khas Daerah Bali sebagai Wisata Kuliner (Culinary Tourism) di Desa Wisata Mengwi Kecamatan Mengwi Kabupaten Badung, dapat ditarik kesimpulan sebagai berikut :

1. Desa Wisata Mengwi mempunyai potensi makanan dan minuman tradisional yang khas, yang dapat dikembangkan sebagai wisata kuliner (culinary tourism). Potensi yang layak dijual kepada wisatawan di Desa Wisata Mengwi telah dicoba untuk dikemas menjadi suatu produk unggulan dan produk alternatif, salah satunya wisata kuliner, dengan memanfaatkan potensi hasil pertanian dan perkebunan.

2. Pengembangan wisata kuliner (culinary tourism) di Desa Wisata Mengwi sebagai media interaksi antara masyarakat dan wisatawan yang bertujuan untuk mencapai keutuhan pengalaman tidak hanya bagi wisatawan, melainkan juga masyarakat desa, dalam rangka meningkatkan kualitas hidupnya.

3. Model kuliner yang dapat dikembangkan di Desa Wisata Mengwi yaitu : makanan pembuka (appetizer) seperti jukut ares, rujak cuka, makanan utama (main course) seperti nasi sela, tipat cantok, babi guling, jukut urab, lawar gedang, ayam/betutu bebek, makanan penutup (dessert) seperti tape ketan, jaja uli, jaja dadar, jaja timus, kolak pisang/sela, minuman seperti es daluman, jus ubi/sela, jus durian, sedangkan untuk camilan seperti sela rebus dan keripik singkong/pisang.

\subsection{Saran}

Kerjasama dengan berbagai pihak yang terkait seperti misalnya pengusaha yang bergerak dibidang pariwisata dan juga dengan pemerintah perlu dilakukan, untuk keberlanjutan pengembangan wisata kuliner (culinary tourism) di Desa Wisata Mengwi, Kecamatan Mengwi, Kabupaten Badung.

\section{UCAPAN TERIMAKASIH}

Kami menyampaikan ucapan terima kasih kepada Rektor Universitas Udayana dan Ketua LPPM Unud yang telah memberikan dukungan dana sehingga kegiatan pengabdian ini bisa berjalan. Terima kasih juga kami sampaikan kepada Dekan Fakultas Pariwisata Universitas Udayana atas fasilitas dan dukungan moral yang telah diberikan. Kepada Kepala Desa Wisata Mengwi, tokoh-tokoh masyarakat dan ibu-ibu PKK Desa Wisata Mengwi yang telah berpartisipasi dan banyak membantu penyelenggaraan pengabdian kepada masyarakat ini kami juga mengucapkan terima kasih.

\section{DAFTAR PUSTAKA}

Aryanta, W. Redi. 1992. The Processing and Microbiological Aspects of Some Traditional Food in Bali, Indonesia. Minatogawa Joshi Tanki Daigaku Kiyo 25 : 188-200. 
Aryanta, W. Redi. 2006. Makalah Pelatihan Penerapan Sanitasi dan Hygiene dalam Pengolahan Makanan Tradisional Bali. Diparda, BTB dan FTP Unud.

Kanca, I Nyoman. 2003. Proses Adaptasi Makanan Khas Bali dalam Menunjang Pariwisata. Artikel Wahana Edisi November. Universitas Udayana.

Sugiono. 1999. Metode Penelitian. Bandung : Alfabet.

Yoeti, Oka A.1982. Pengantar Ilmu Pariwisata. Aksara Bandung. 